Eur. J. Clin. Chem. Clin. Biochem.

Vol. 32, 1994, pp. 349-353

(c) 1994 Walter de Gruyter \& Co.

Berlin - New York

\title{
Plasma Myoglobin in the Early Diagnosis of Acute Myocardial Infarction
}

\author{
By Anna Maria Castaldo ${ }^{1}$, Paola Ercolini ${ }^{1}$, Francesca Forino ${ }^{1}$, Adalgisa Basevi ${ }^{1}$, L. Vrenna $^{1}$, Paola Castaldo ${ }^{1}$, \\ V. D'Ambrosio' ${ }^{2}$, and A. Castaldo ${ }^{1}$ \\ 1 Laboratorio di Patologia Clinica, Ospedale "Cardinale Ascalesi", Napoli, Italy \\ 2 Chirurgia d'Urgenza, Ospedale "Cardarelli", Napoli, Italy
}

(Received November 19, 1993/February 2, 1994)

Summary: Serum and plasma myoglobin and creatine kinase-MB catalytic activity were analysed in 157 patients admitted within 2 hours of the onset of chest pain ( 58 were retrospectively recognized as acute myocardial infarction).

Serum and plasma values were highly correlated for both myoglobin and creatine kinase-MB.

Plasma myoglobin appared to be more sensitive than creatine kinase-MB for the early diagnosis of acute myocardial infarction; using a cut-off value of $100 \mu \mathrm{g} / \mathrm{l}, 90 \%$ of acute myocardial infarction cases were correctly recognized by plasma myoglobin 6 hours after the onset of chest pain, with a diagnostic specificity of $100 \%$ for non-acute myocardial infarction chest pain subjects. Plasma creatine kinase-MB showed a diagnostic sensitivity of $62 \%$ and a diagnostic specificity of $95 \%$ in the same group of patients.

We suggest the inclusion of the plasma myoglobin immunonephelometric assay together with plasma creatine kinase-MB activity analysis in protocols for the early diagnosis of acute myocardial infarction.

\section{Introduction}

Serum myoglobin is a very early marker of acute myocardial infarction, even in patients without typical electrocardiographic changes (1). Various authors, including our research group (2), have shown that serum myoglobin provides an earlier diagnosis of acute myocardial infarction than does serum creatine kinase-MB isoenzyme activity, which was previously considered the biochemical "cornerstone" for acute myocardial infarction diagnosis (3).

Until 4-5 years ago, however, the methods for serum myoglobin assay were a radioimmunoassay (4) scarcely suitable for an emergency laboratory, and the latex agglutination method $(5,6)$, a semiquantitative procedure with an insatisfactory diagnostic sensitivity.

More recently, a turbidimetric assay (7) with excellent analytical performance (8) and a nephelometric assay (9) have been suggested for serum myoglobin assay, and our group first reported the very satisfactory correlation of this latter method with the radioimmunoassay $(2,10)$; thus, these "alternative" procedures have been used in recent years for both acute myocardial infarction diagnosis and infarct size determination (11), and more recently for the evaluation of coronary reperfusion after thrombolytic therapy (12).

To further increase the rapidity of acute myocardial infarction diagnosis in chest pain subjects, we suggested the assay of plasma instead of serum myoglobin (13), since preliminary studies showed a high correlation between plasma and serum myoglobin immunonephelometric assays.

We report results obtained over a period of two years for the early diagnosis of acute myocardial infarction in a group of non-selected chest pain patients, using the measurement of plasma and serum myoglobin and the assay of creatine kinase-MB activity. 


\section{Materials and Methods}

Patients

We studied 157 patients admitted within 2 hours from the onset of chest pain; 101 were males, aged between 33 and 72 (median 58) and 56 were females ( 38 to 80 years, median 61 ). The studied population was referred from the emergency cardiology department of the two major hospitals of our region, and includes only those subjects with a high prediction of acute myocardial infarction.

Retrospectively, 58 patients ( 41 males and 17 females) were diagnosed as affected by acute myocardial infarction according to the World Health Organization criteria (14) based on clinical, electrocardiographic and enzymatic data; the results of myoglobin were not provided to the physicians; 38 patients $(66 \%)$ with acute myocardial infarction received intravenous thrombolytic therapy; the others were not given the therapy, because of various contraindications.

Among non-acute myocardial infarction subjects, $28 \%$ were suffering from unstable angina pectoris, $23 \%$ from pneumonitis or pulmonary embolism, $17 \%$ from pericarditis, $16 \%$ from gastric ulcer or gastritis; for the remaining subjects there is no definite diagnosis. None of the patients had received intramuscular injections on admission, and none had clinical findings of skeletal muscle injury.

For each patient, blood was sampled 3, 6, and 9 hours after the onset of chest pain, using both a lithium heparin vacutainer (Becton Dickinson) and a vacutainer with no anticoagulant. The samples were centrifuged ( $5 \mathrm{~min}$ at $2500 \mathrm{~g}$ ) and processed for the analyses of creatine kinase-MB and myoglobin.

\section{Methods}

Serum and plasma creatine kinase activity was analysed at $37^{\circ} \mathrm{C}$ on the Spectrum 2 analyser with reagents from Abbott (North Chicago, IL) using the immunoinhibition procedure (Abbott) for the estimation of creatine kinase-MB isoenzyme activity.

Serum and plasma myoglobin were analysed using the immunonephelometric (NA-Latex, Behringwerke, Marburg, Germany) method.
Tab. 1 Correlation (regression analysis, $y=$ plasma; $x=$ serum) between serum and plasma assays of myoglobin and creatine kinase-MB $(y=a+b x)$

\begin{tabular}{lccccc}
\hline & $\mathrm{N}$ & $\mathrm{a}$ & $\mathrm{b}$ & $\mathrm{r}$ & $\mathrm{Syx}$ \\
\hline Myoglobin $(\mu \mathrm{g} / \mathrm{l})$ & 47 & 1.7 & 0.973 & 0.982 & 1.037 \\
$\begin{array}{l}\text { Creatine kinase-MB } \\
\quad \% \text { of total }\end{array}$ & 47 & -0.11 & 1.002 & 0.969 & 0.096 \\
$\quad$ (creatine kinase) & & & & & \\
\hline
\end{tabular}

\section{Results}

The correlation between serum and plasma values of myoglobin and creatine kinase-MB was tested on 48 samples obtained from patients with acute myocardial infarction; in both cases, the correlation was excellent (tab. 1) for analytical values extending over a very wide range.

The intra-day and between days imprecision of the methods for myoglobin analysis $(\mathrm{CV} \%=3.9$ and 7.8 respectively), and for creatine kinase activity estimation $(\mathrm{CV} \%=5.1$ and 8.9 respectively) indicates the low variability of both the methods.

Tables 2 to 4 report the values for diagnostic sensitivity and specificity and positive and negative predictivity of plasma myoglobin and creatine kinase-MB in the discrimination between acute myocardial infarction and non-acute myocardial infarction chest pain patients, tested 3, 6 and 9 hours from the onset of chest pain. The number of non-acute myocardial infarction control patients gradually decreases; this is due to the percentage of subjects dismissed from the emergency cardi-

Tab. 2 Diagnostic performances of plasma creatine kinase-MB and myoglobin for acute myocardial infarction diagnosis 3 hours after onset of chest pain

\begin{tabular}{lllllll}
\hline & Cut-off & $\begin{array}{l}\text { Diagnostic } \\
\text { sensitivity }\end{array}$ & $\begin{array}{l}\text { Diagnostic } \\
\text { specificity }\end{array}$ & $\begin{array}{l}\text { Positive } \\
\text { predictive value }\end{array}$ & $\begin{array}{l}\text { Negative } \\
\text { predictive value }\end{array}$ & $\begin{array}{l}\text { Youden } \\
\text { index }\end{array}$ \\
\hline $\begin{array}{l}\text { Creatine kinase- } \\
\text { MB }\end{array}$ & $\begin{array}{l}5 \% \text { of total } \\
\text { creatine kinase }\end{array}$ & $22 \%$ & $98 \%$ & $87 \%$ & $66 \%$ & 20 \\
$\begin{array}{l}\text { Myoglobin } \\
100 \mu \mathrm{g} / \mathrm{l}\end{array}$ & $38 \%$ & $100 \%$ & $100 \%$ & $71 \%$ & $\ldots$ & 38 \\
\hline
\end{tabular}

Tab. 3 Diagnostic performances of plasma creatine kinase-MB and myoglobin for acute myocardial infarction diagnosis 6 hours after onset of chest pain

\begin{tabular}{lllllll}
\hline & Cut-off & $\begin{array}{l}\text { Diagnostic } \\
\text { sensitivity }\end{array}$ & $\begin{array}{l}\text { Diagnostic } \\
\text { specificity }\end{array}$ & $\begin{array}{l}\text { Positive } \\
\text { predictive value }\end{array}$ & $\begin{array}{l}\text { Negative } \\
\text { predictive value }\end{array}$ & $\begin{array}{l}\text { Youden } \\
\text { index }\end{array}$ \\
\hline $\begin{array}{l}\text { Creatine kinase- } \\
\text { MB }\end{array}$ & $\begin{array}{l}5 \% \text { of total } \\
\text { creatine kinase }\end{array}$ & $62 \%$ & $94 \%$ & $86 \%$ & $81 \%$ & 56 \\
Myoglobin & $100 \mu \mathrm{g} / 1$ & $90 \%$ & $100 \%$ & $100 \%$ & $94 \%$ & 90 \\
\hline
\end{tabular}


Tab. 4 Diagnostic performances of plasma creatine kinase-MB and myoglobin for acute myocardial infarction diagnosis 9 hours after onset of chest pain

\begin{tabular}{lllllll}
\hline & Cut-off & $\begin{array}{l}\text { Diagnostic } \\
\text { sensitivity }\end{array}$ & $\begin{array}{l}\text { Diagnostic } \\
\text { specificity }\end{array}$ & $\begin{array}{l}\text { Positive } \\
\text { predictive value }\end{array}$ & $\begin{array}{l}\text { Negative } \\
\text { predictive value }\end{array}$ & $\begin{array}{l}\text { Youden } \\
\text { index }\end{array}$ \\
\hline $\begin{array}{l}\text { Creatine kinase- } \\
\text { MB }\end{array}$ & $\begin{array}{l}5 \% \text { of total } \\
\text { creatine kinase }\end{array}$ & $97 \%$ & $94 \%$ & $95 \%$ & $96 \%$ & 91 \\
$\begin{array}{c}\text { Myoglobin } \\
100 \mu \mathrm{g} / 1\end{array}$ & $100 \%$ & $100 \%$ & $100 \%$ & $100 \%$ & 100 \\
\hline
\end{tabular}

ology department after the exclusion of acute myocardial infarction.

For myoglobin and creatine kinase-MB we used a cutoff value of $100 \mathrm{~g} / \mathrm{l}$, and $5 \%$ of total enzyme activity, respectively. These values had been previously calculated with the receiving operator characteristic curve analysis as the best discriminating cut-off between acute myocardial infarction and non-acute myocardial infarction chest pain subjects (2), and are used routinely in our laboratory.

Plasma myoglobin appeared to be a more efficient biochemical marker than creatine kinase-MB, being increased in $90 \%$ of acute myocardial infarction patients 6 hours after the onset of chest pain, with a diagnostic specificity of $100 \%$ for non-acute myocardial infarction chest pain patients.

\section{Discussion}

In recent years, the use of thrombolytic therapy has reduced myocardial damage and mortality in acute myocardial infarction patients; however, such therapy must be used during the first hours after the onset of myocardial necrosis, thus requiring a very early and specific biochemical diagnosis, particularly in patients with unclear electrocardiographic data.

An early biochemical diagnosis of acute myocardial infarction cannot be based on serum creatine kinase-MB activity, since this marker peaks too late during acute myocardial infarction. Our data confirm that the release of myoglobin in acute myocardial infarction patients is an earlier event than creatine kinase-MB release, as previously described on a large population (15); in fact, $40 \%$ and $90 \%$ of acute myocardial infarction patients can be identified with the plasma myoglobin assay after three and six hours from the onset of symptoms, respectively, while the percentage of acute myocardial infarctions identified with creatine kinase-MB activity assay is significantly lower. These results are particularly interesting, because electrocardiographic data are inconclusive for a certain percentage of acute myocardial infarction patients; in our population (data not shown), the results of electrocardiography were inadequate for a conclusive diagnosis in about $10 \%$ of acute myocardial infarction cases. In addition, the evaluation of myoglobin has been reported as a useful marker for evaluation the myocardial reperfusion after thrombolytic therapy (16).

Recently, Mair et al. (17) reported that the mass concentration of creatine kinase-MB provides an earlier diagnosis of acute myocardial infarction than does its catalytic concentration. Our preliminary results on a small sample of acute myocardial infarction cases (data not shown) confirm these results.

Our two-years experience has confirmed that the immunonephelometric procedure for myoglobin analysis makes an important contribution to diagnosis. Evaluated against classical quality control methods, the procedure was shown to be precise and accurate. It is also rapid, so that were able introduce the procedure into the laboratory routine as an alternative to the previously used radioimmunoassay method.

Cut-off values of $100 \mu \mathrm{g} / \mathrm{l}$ for myoglobin and $5 \%$ of total enzyme activity for creatine kinase-MB, previously revealed by the receiver operating characteristic curve analysis (2), gave the best discrimination of acute myocardial infarction from non-acute myocardial infarction chest pain patients in our population; this cut-off, recently confirmed by the group of Bakker (18), is slightly higher than the value of $90 \mu \mathrm{g} / \mathrm{l}$ suggested by the producer of the immunonephelometric kit for myoglobin analysis, and which has been evaluated in a healthy control reference population. A higher cut-off value gives a diagnostic specificity of $100 \%$ for discrimination of the acute myocardial infarction group from non-acute myocardial infarction patients. Also, during our two years study, myoglobin values higher than $100 \mu \mathrm{g} / \mathrm{l}$ were observed in a small percentage of patients with skeletal muscle injury (data not reported), but such diseases rarely require a discrimination from acute myocardial infarction. However, when the chest is accompanied by clinically evident muscular damage, it should be borne in mind that serum/plasma myoglobin or creatine kinase-MB can also be released from skeletal muscle. In 
these cases, it is important to consider all the clinical, electrocardiographic and laboratory data together, rather than a single biochemical marker.

At the moment, myoglobin appears to be the most reliable biochemical marker for the early diagnosis of acute myocardial infarction. Other approaches have been recently suggested, such as creatine kinase isoform analysis (19), particularly the serum MM3/MM1 ratio, whose alteration is a very early event in acute myocardial infarction patients. However, the use of this approach is limited, since serum creatine kinase isoforms can only be analysed by electrophoresis, isoelectric focusing and liquid chromatographic methods, which are inadequate for a rapid routine analysis. The use of the immunological procedure is still questionable, since the group of Suzuki (20) described various monoclonal antibodies for creatine kinase isoforms with different analytical specificities.

The other result of our study is the very high correlation between serum and plasma myoglobin and creatine kin-
ase-MB, obtained in a large group of patients with values of the two analytes ranging over a wide range of values. This result confirms our preliminary observation (13) that the use of lithium heparin as anticoagulant does not affect the myoglobin and creatine kinase-MB immunological assays, and does not inhibit creatine kinase enzyme activity. These data agree with another preliminary result from 10 acute myocardial infarction cases (8) and with a study published by the group of Mair (15) which used a different anticoagulant.

The use of plasma instead of serum myoglobin is a useful approach, reducing by about 20 minutes the time required for a conclusive diagnosis of acute myocardial infarction; in addition, the same sample can also be used for creatine kinase-MB analysis.

We conclude that the nephelometric assay of plasma myoglobin should be included, together with immunological creatine kinase-MB analysis, as a primary contributory tool in the protocols for the diagnosis of acute myocardial infarction in patients on their first day of admission.

\section{References}

1. Ohman, E. M., Casey, C., Bengston, J. N., Pryor, D., Tormey, W. \& Horgan, J. H. (1990) Early detection of acute myocardial infarction: Additional diagnostic information from serum concentrations of myoglobin in patients without ST elevation. Br. Heart J. 63, 335-338.

2. Vrenna, L., Castaldo, A. M., Castaldo, P., Giardiello, D., Di Giacomo, C., Esposito, L. P. \& Romano, F. (1992) Comparison between nephelometric and RIA methods for serum myoglobin, and efficiency of myoglobin assay for early diagnosis of myocardial infarction. Clin. Chem. 38, 789-790.

3. Lott, J. A. \& Stang, J. M. (1980) Serum enzymes and isoenzymes in the diagnosis and differential diagnosis of myocardial ischemia and necrosis (Review). Clin. Chem. 26, 12411250.

4. Gilkeson, G., Stone, M. J. \& Waterman, M. R. (1978) Detection of myoglobin by radioimmunoassay in human sera: Its usefulness and limitations as an emergency room screening test for acute myocardial infarction. Am. Heart J. 95, 70-77.

5. Chapelle, J. P. \& Heusghem, C. (1985) Semi-quantitative estimation of serum myoglobin by a rapid latex agglutination method: An emergency screening test for acute myocardial infarction. Clin. Chim. Acta $145,143-150$.

6. Norregaard-Hansen, K., Hangaard, J. \& Norgaard-Pedersen, B. (1984) A rapid latex agglutination test for detection of elevated levels of myoglobin in serum and its value in the early diagnosis of acute myocardial infarction. Scand. J. Clin. Lab. Invest. $44,99-103$.

7. Metzmann, E., Schmidt, B., Dengler, M. \& Kapmeyer, W. (1988) Quantitative Myoglobinbestimmung mit einem turbidimetrischen Latextest (Abstract). J. Clin. Chem. Clin. Biochem. 26,760 .

8. Delanghe, J., Chapelle, J. P., El Allaf, M. \& De Buyzere, M. (1991) Ann. Clin. Biochem. 28, 474-479.

9. Kapmeyer, W., Pauly, H. E. \& Tuengler, P. (1988) Automated nephelometric immunoassays with novel shell/core particles. J. Clin. Lab. Anal. 2, 76-83.
10. Vrenna, L., Castaldo, A. M., Castaldo, P., Giardiello, D., Di Giacomo, C., Esposito, L. P. \& Romano, F. (1991) Correlazione tra metodo immunonefelometrico e radioimmunologico per il dosaggio della mioglobina sieríca e precocità diagnostica nell' infarto del miocardio. Giom. It. Chim. Clin. 16, 387-392.

11. Delanghe, J. R., De Buyzere, M. L., Cluyse, L. P., Thierrens, H. M. \& Clement, D. L. (1992) Acute myocardial infarction size and myoglobin release into serum. Eur. J. Clin. Chem. Clin. Biochem. 30, 823-830.

12. Arima, S., Nomoto, K., Maruyama, I., Miyata, M., Yamaguchi, H., Okino, H., Yamashita, T., Atsuchi, Y. \& Tahara, M. (1993) Early detection of coronary reperfusion by rapid assessment of plasma myoglobin. Int. J. Cardiol. 38, 33-40.

13. Castaldo, A. M., Vrenna, L., Castaldo, P. \& Di Giacomo, C. (1992) Correlazione tra dosaggio plasmatico e sierico della mioglobina nella diagnosi precoce di infarto del miocardio. Giorn. It. Chim. Clin. 17, 129-130.

14. World Health Organization (1981) WHO criteria for the diagnosis of acute myocardial infarction. Proposal for the multinational monitoring of trends and determinants of cardiovascular disease. Geneva, WHO.

15. Mair, J., Artner-Dworzak, E., Lechleitner, P., Morass, B. Smith, J., Wagner, I., Dienstl, F. \& Puschendorf, B. (1992) Early diagnosis of acute myocardial infarction by a newly developed rapid immunoturbidimetric assay for myoglobin. Brit. Heart J. (1992) 68, 462-468.

16. Katus, H. A., Diederich, K. W., Scheffold; T., Vellner, M., Schwarz, F. \& Kubler, W. (1988) Non invasive assessment of infarct reperfusion: The predictive power of the time to peak value of myoglobin, CK-MB and CK in serum. Eur. Heart $J$. 9, 619-624.

17. Mair, J., Artner-Dworżak, E., Dienstl, A., Lechleitner, P., Morass, B., Smidt, J., Wagner, I., Wettach, C. \& Puschendorf, B. (1991) Early detection of acute myocardial infarction by 
measurement of mass concentration of creatine kinase-MB. Am. J. Cardiol. 68, 1545-1550.

18. Bakker, A. J., Boymans, D. A. G., Dijkstra, D., Gorgels, J. P. M. C. \& Lerk, R. (1993) Rapid determination of serum myoglobin with a routine chemistry analyzer. Clin. Chem. 39, 653-658.

19. Panteghini, M., Cuccia, C., Malchiodi, A., Malarco, M. \& Pagoni, N. (1986) Isoforms of creatine kinase $M M$ and $M B$ in acute myocardial infarction: A clinical evaluation. Clin. Chim. Acta $155,1-10$.
20. Suzuki, T., Shirashi, T., Tomita, K., Totani, M. \& Murachi, T. (1990) Monoclonal antibody inhibiting creatine kinase MM3 but not isoform MM1. Clin. Chem. 36, 153-156.

Luigi Vrenna

Laboratorio di Patologia Clinica

Ospedale "Cardinale Ascalesi"

via Egiziaca a Forcella

I-80100 Napoli

Italy 
